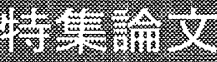

\section{日本企業における企業統治システム設計の㹎題}

\section{青 井 倫 一*}

現在の日本企業において企業統治の課題によ゙う対応すべきかという大きな問題が生じている。ア メリカン・スタンダードに対して日本型を主張する意見む多い。しかし，この企業統治の問題は日 本企業における経営システムの根幹の議論であり，90年代からの環境変化によってこれまでの“日 本的経営の錆付いた機能”が明らかになったというべきである。

グローバル競争の激化，直接金融への依存等の“ゲームのルール”の変化に有効に対応するため に日本企業における意思決定プロセスの再構築が求められている。

多くの企業統治論はシステムの变革を論じている。しかし，同等に重要なことは CEOの付加価 值である。この論文では “CEOのリーダーシップ”と“取締役会”のインタラクティブな緊張感 のあるシステムの設計を勧める。

キーワード：コーポレイトガバナンス, 日本企業の戦略, トップマネジメントの付加価值, 取締役会

\section{1.はじめに}

現在，多くの日本企業においてこれまでの企業 戦略のありかたの再検討がなされ，企業の経営シ ステム革新のひとつとして, 現状の取締役会の制 度改革, また取締役とはどうあるべきかという経 営制度（システム）の再設計がなされている。企 業によってそのような改革の形は異なるが, 取締 役と執行役員の分離, 少数のメンバーからなる活 性化された取締役会, 社外取締役の活用, 諮問委 員会の設定, 監査委員会の充実といった種々の変 革の試みがなされていることは新聞・雑誌の報道 によってよく知られている。しかし，これらの企 業経営システム（企業統治）の変革が単なる流行

\footnotetext{
"縻應荺塾大学大学院経営管理研究科
}

による“形だけのもの”に終始しないために, 換 言すれば，これらの変革の試みが日本企業におけ るバイタリティーの再生, 日本社会における経営 資源の効率的活用の達成という成果を生むことを 期待するために，企業統治という経営システムの 変革をこの論文で検討することにする。

過去においても企業統治の問題が日米構造協議 において議論されたが, その際の議論は結果とし て「株主代表訴訟」という項目に“不適切に集約” された感がある。企業統治の問題は T. フリード マン流に表現すれば日本企業の経営システムにお ける “OSの変更”というレベルであって, “ア プリケーションプログラムの追加”というレベル の問題ではない。その認識が企業関係者にとって 極めて重要である。

“いかに企業を運営すべきか（how to run the company)” という課題についてはこれまで 
多くの研究が集中してきたといえるが（ビジネス スクールのカリキュラムの対象でああった), そ れに対して“いかに企業を統治すべきか（how to govern the company)” という課題には関心 が払われることはあまりなかったといえる。とは いっても日本企業・社会だけがこのような企業統 治という問題に関心を払うのを怠ってきたという ことではない。企業統治（コーポレイト・ガバナ ンス）という表現自体は世界的にみてもそう古い ものではないといえる。ここ10数年の話であると いってよい（70年代には企業の社会的責任論とい う形での展開はあったが)。米国，英国において 屯企業統治システムへの関心がそれぞれ少し異な る理由で高まり，かれらなりにベスト・プラクティ スは何かを検討している。

まず企業統治のシステム設計論を展開するにあ たって，最初に着手しなければならない作業は， それぞれの国でなぜ企業統治という課題が注目を 受ける状況になったかという“診断”の作業であ る。個々の国, 地域の診断（需要分析）に応じて 処方等を書くことが適切であると思われる。例え ば，日本に扔いて10年ほよ゙前には“日本的経営論” が全盛期であり，“経営者資本主義”が“株主資 本主義”にとって代わるといわれた。日本経済の 成果を背景に, “日本的経営システム（経営者資 本主義)”に自信を持った企業経営者が多かった。 にあかかわらず，今なぜ日本企業の経営システム そのあのの戦略的再検討が流行しているのかとい うことである。おし日本企業の外部環境が構造的 に不変で日本企業が単なる景気循環の底に位置す るだけであれば，経営システムの改革の必要性は さほど高くないといえる。その場合“今のままで 我慢する”というのが日本企業にとって優れた戦 略対応ともいえるかもしれない。しかし，企業環 境に構造的変化が生じている場合, “我慢という 現状維持”選択の有効性は疑問である。“我慢す る”ことによって日本企業は，よく言われる“ゆ でガェル現象”となってしまう可能性が高いと思
われる。われわれとしては企業統治の問題は戦後 に確立し，強化されてきた“企業”に対するわれ われの基本的作業仮説を大幅に変更する契機にな ると判断している。

そこで 2 節において現在の日本のビジネス社会 において「企業統治」への需要がなぜ高まりをみ せつつあるのかを主として企業戦略变革の視点か ら考察する。「取締役会の改革」の動きは企業の 外加らの圧力というよりは，企業環境の変化に対 応するべく企業内部からの動きと判断するほうが 適切である。ただ，多くの企業に抢いては「取締 役」についての従来の “感覚” が延長線しして残っ ているので企業統治論に若干の混乱をもたらして いる。

3 節に打いては米国, 英国の動向を分析するこ とにする。留意しなければならないのは企業統治 の形に唯一という解は存在しないという認識であ る。海外の企業統治の形をそのまま日本社会に輸 入するのは適切でないのはいうまであない。企業 は社会・市場という枠組のなかで活動する組織で あるから，企業が立脚する社会・市場の構成員の 価值観に大きく依存するのは当然である。と同時 に市場のグローバル化の進展によって“国内市場 の論理”にコッミトし続けることあ困難になって いる。社会, 市場の要請する方向性が多様化して いる状況での企業統治というすのを考察しなけれ ばならない。したがって各国の優れた考えを参考 にして日本に抢ける企業統治のベスト・プラクティ スを策定しつづけるという作業が現在, そして将 来においても必要になる。

そして 4 節において日本に打ける企業統治の議 論を整理することにする。ここで考慮する対象の 企業としては, 基本的に大規模公開会社を想定し ている。したがって経営と所有の分離から生じる 「エージェンシーの問題」が中心課題となる。ま たその整理は会社法などの法律的アプローチでは なく, 経営学的視点を中心にして展開することに する。といっても法律的アプローチが重要ではな 
いということではなく, 企業統治自体は極めて学 際的な課題であり，それらを統合することの重要 性をここで指摘しておく。

\section{2.日本企業における企業統治論への “需要分析”}

この 2 年間において日本企業の多くにおいてな ぜ企業統治における变革が高まったのかといえば, それは90年代のバブル崩壊から低迷する企業業績 からいかにして立ち直るかという試みの一環とい えるであろう。それまでの日本企業の戦略の最大 公約数であった“日本経済の成長に乗る”という ことがバブルの崩壊後持続できなくなり，この数 年間の貧しい経営実績からみて単純な既存路線の 延長線では企業の存続が期待できなくなるという 判断が背景にある。そこでこれまでの企業戦略・ 事業戦略を根本加ら再編するための意思決定プロ セスの模索が必要になったからである。ある意味 では事業部門の代表者からなる形骸化したこれま での取締役会の付加価值が問われるようになった といえる。このような取締役会の付加価值を問い, 企業統治の新しい仕組を要求するようになった理 由をバランス・シートの左側である事業戦略, 右 側である財務戦略, そして企業不祥事に対する社 会の圧力という視点で整理することにする。

\section{（1）成長から競争へ}

これまでの日本企業が最大の関心を向けてきた のが顧客 (製品市場) である。この製品市場にお いてグローバル競争の激化ということがこの10年 加速している。そして “勝ち組と負け組の選別” という表現に代表されるように，製品市場に参加 しているすべての企業が事業収益を上げられる成 長の時代ではすでになくなっている。換言すれば “ほどほどの経営資源の投入”で“ほよ゙ほどの収 益”が保証されるような市場環境ではなくなりつ つあるといってよい。
したがってよく言われるように“選択と集中” ということの実践が企業戦略においてまったなし に必要条件となってきている。これまでの日本企 業は経営資源の（量的）蓄積には注力してきた （そしてそれが日本企業の優位性といわれた）と いえるが，グローバル競争の激化と一部市場の成 熟化により，市場の選択と投入経営資源のタイミ ング (鮮度) および投入量の組み合わせによって 事業成果が大きく変わるようになり, 企業が経営 成果を示すためには特徵のない事業ポートフォリ オ戦略から企業の持つ強みが発揮できると判断さ れるコア事業への経営資源集中が戦略的に必須之 いう状況になっている。言い換えれば，これまで は“スクラップ\&ビルド” 戦略の遂行と日本企業 は表明してきてはいたが, 経営資源の量的蓄積を 資源の効率的活用よりも重視してきたために，結 果として“ビルド\&ビルド”の戦略を遂行すると いう結果になった。

しかし，市場競争に抒ける“ゲームのルール” の推移によって成長から競争へと中心課題が推移 して，市場の競争圧力から，どの事業を優先すべ きかの事業選択を迫られつつある。本当の意味で の“スクラップ\&ビルド”戦略というこれまで実 施してこなかった『不連続性のマネジメント』を 実施せざるをえない状況に追い込まれている。い まさら“ビルド\&ビルド”戦略が単純に成果を生 んだ“昔のよい時代”を振返って懐かしんでも仕 方がないという“忘れ去る”という割りきりが企 業にとって必須になったといってよいのではなか ろうか。

そして経営成果の評価という点で, 経営者が受 託者責任を十分に果たしているのかという厳しい 疑問が，企業戦略は株主の利益に正当な関心を払っ ているのかという質問として株主から投げかけら れているのが現在の日本企業である。

\section{（2）間接金融から直接金融へ}

しかもこのような“選択と集中”を加速する市 
場の圧力が，企業のバランス・シートの右側にお ける変化からあ起こりつつある。これまでの銀行 からの資金に依存する間接金融の時代から直接金 融の時代へと移行することによって企業の資金調 達における社債・株式の占める重要性が高まりつ つある。資金調達において少数の銀行に依存でき なくなり，フリードマンのいう“ファイナンスの 民主化”に企業が対応しなければならなくなった のである。当然，株主価值の最大化という投資家 に対する経営課題が企業経営にリアルに反映しな くてはならない状況になっている。また社債にお いては“確実に借金を返済できるかという尺度 (情報)”として第三者による判断である『格付』 という概念が重要になる。社債市場においては多 くの投資家の判断に対する適切な企業からの情報 提供が必要ということで, 透明性ということを担 保する“情報開示”ということが企業にとって避 けられないこととなる。これまでのように企業が 少数の銀行家の監視に耐えられればことたりると いう時代ではなくなっている。

一方，株主（投資家）の視点に立てば，株主の 期待する収益性を企業戦略が株主持分をべースに 創出できるかという保証を当然要求するであろう。 単に, 企業が会計上の黒字を計上しているだけで は株主からみた企業経営の最適性を保証するもの ではない。企業戦略の策定において株主持分の機 会費用（資本コスト）を考慮することがあたりま えである。その要求に答えられない企業に対して は, 資本市場の厳しい対応が待ち受けている。キャ シュフロー経営, MVAという表現が自然に使用 されるのである。バランス・シートの “左側”で 成長戦略を描くことあ困難になりつつあるが，た とえ描けたとしてあ, バランス・シートの右側で の対応 (財務戦略) が適切でなければ, 企業その あのの成長の速度はずるずると下降していく時代 感覚が主流となっている。

過去の “株式持合システム”が崩壊し, 外人株 主が増加し, “普通の株主”が増加すれば,これ
まで蓄積した経営資源を有効に市場で活用して正 当な経営成果を出しているかというあたりまえの 問いが出現するのは自然であろう。そのような株 主の問いかけに答えるために ROE の向上とか株 主価值最大化というものが企業経営の重要課題之 して登場している時代となってきているのである。 だからといって製品市場・資本市場は格段特別 なことを企業に要求しているのではない。極めて 自然な要求をしているのである。公開企業は健全 な『営利組織』として生存するようにとの要求を しているという認識が企業経営者にとって大切で あろう。そして株主持分に依る健全な営利組織で あり続けるための仕組の構築が企業統治の再検討 という形で浮上してきたといえる。低収益・遅い 意思決定というこれまでの日本企業の欠点とされ た項目に対して営利組織として存続するための “処方箋”を描くという作業が始まったのである。

\section{（3）社会のなかの企業}

ここまで製品市場における“ゲームのルール” の変更, バランス・シート右側の重要性の認識と いうことを強調してきた。しかし，あうひとつ経 営, ことにコーポレイト・ガバナンスに扔いて考 慮しなければならない重要な点は, いくつか続い た企業の不祥事への世間の非難, それへの対応と いうこともいえるのではなかろうか。企業は営利 組織であるとの認識が必須であることはいうまで あないが, 営利行動以前に, 企業む社会的存在で あるという認識がより重要となる。となると，日 本社会, さらには世界各地において自社の行動に おける『規範, 規律』ということをどう設定すべ きかということを正面から考えねばならない。こ とにこれから権限の委譲ということが企業にとっ て市場の変化に対応する際, 必須な設計原理とな るので, “勝てば官軍”之か“裁量に任せる，う まくやれ”といった類のこれまでの日本企業に特 有の経営モードは許されるものではなくなる。将 来において, 倫理・環境問題と多くの社会的課題 
に直面するであろう社員に対して企業の価值観を 明確に提示して，しかもそれらが守られているか どうかの監査を企業自体がすることが望まれよう。 とかく横並びになりがちな売上至上主義, 収益至 上主義，株主価值至上主義に対して，企業行動が とりうる行為の集合に対する企業自身の価値観の 明確化，当社はこのような原則にこだわるという 厳格な“内部統制, 内部監查”を伴う『企業行動 規範』のありかたが社会から問われる。企業にお けるミッション・ビジョンが何かを明確にするこ とが要求され，そしてそれに対応するガバナンス 構造も考えねばならないであろう。

以上述べた視点を要約すれば，企業を『外部の 視点からみること』をどのようにして企業の意思 決定プロセスに組み込むのかをそれらは要請する ものといえる。日本においては企業，会社はとか く“閉じた社会”になりがちで，会社内部の視点 であのごとを判断してきた。しかし，『株主とい う他人』, 『市場・社会に打ける他人』という視点 で企業の行動，そして構造を評価した際には，ど のような評価がされるのかを企業は市場・社会よ り先取りしなければならないのではなからうか。 『顧客の視点』、社員の視点』ということには十 分配慮してきた過去の日本企業ではあったが，こ れからは社会における健全な営利組織としてどう あるべきか，そのことを含めた『企業設計』を現 在要求されているといってよいであろう。

\section{3. 企業統治における欧米の動向}

企業統治の形は国によって，また時代によって 異なる。したがって日本企業の企業統治の設計に 扔いて“企業統治の直接輸入”が好ましいもので はないともいえる。しかし，海外での企業統治が どのような理由で起こり，どのような形であるか を整理することは大いに参考になると思われる。 日本に拈いては米国型, ドイッ型といった企業・ 株主・取締役会そして監査役会（ドイッ）の“形
（株主，株主総会，取締役会，監查役会，そして マネジメントの配置)”の比較がなされるが，そ れらの“形”の比較よりは，それぞれの国におけ る企業統治の変遷を歴史的に分析することのほう がより価值のあることである（長い証券市場の歴 史，したがって経験豊富な米国に学ぶ必要はこと に大きい)。しかしそれは他の論文に譲り，ここ では最近の米国・英国の動向の簡単な整理に留め ることにする。

\section{（1）米国の動向}

米国に抒ける企業統治の最近の動向はまさに機 関投資家の活動によるものであることはよく知ら れている。ここで投資家（株主）の性格について 整理しておくことが機関投資家の動向を理解する ために便利である。例えば野村證券金融研究所に よれば投資家の類型をトレーダー，ガバナンス重 視, 経営戦略関与型に分類している。トレーダー に類型化されるのは多くの個人投資家であり，一 銘柄あたりの投資額は小さいので投資においては ウォールストリート・ルールを採用する。したがっ て議決権の行使に関して無関心となる。そこで, “企業戦略を評価しなければタイミングをみて売 却”という対応をする。しかし，ガバナンス重視 型のカルパースのような公的年金基金，その他の 大型年金基金の場合，分散投資をしてはいるが巨 大なファンド規模であるので 1 銘柄あたりの投資 規模は大きい。そこで投資収益の向上のためには トレーダー型のような対応はできず，企業戦略の 効率化，そのためのガバナンス構造変革に対して 議決権の行使を積極的に行うようになる。買収ファ ンドや資本家的な経営戦略関与型の投資家は少数 の銘柄へ集中投資をするので経営陣の交代や取締 役を送り込むことによって経営戦略に関与し，投 資収益を向上しようとする。

米国において80年代後半において敵対的買収。 LBO の盛んな時期があった。その際にターゲッ トとなった企業の経営陣は敵対的買収防衛策で対 
抗した。しかし，この対応が株主の利益に沿うも のかどうかという疑いから一部の公的年金が企業 にいろいろな株主提案をしたのは記憶に残ってい るであろう。その後, このような買収ゲームのブー ムが終わり，90年代前半，米国企業の業績不振の 時期に, 業績不振企業を対象にして CEO の交代, $\mathrm{CEO}$ の報酬額の改革を公的年金や一部の企業年 金が企業と直接交渉を行った。そして90年代後半 になって企業業績が好調になっても，取締役会の 構造が不備な企業を対象に企業年金, 労働組合年 金も参加して取締役会改革・経営者報酬制度など をテーマにして株主権を行使したのであった。た とえば有名なカルパースの原則は

1. 説明責任

2. 透明性

3. 公正性

4. 議決権行使方法の改善

5. 最善の行動規範採用

6. 長期ビジョン となっている。

以上のように米国での最近の企業統治の動向に おいては投資収益の向上を求める機関投資家（公 的年金, 企業年金, 組合年金)の要請によるもの である。

\section{（2）英国の動向}

英国における企業統治の動向はキャドバリー報 告, グリーンベリ一報告, そしてハンペル報告に 代表される。キャドベリ一委員会では, 企業統治 とは企業が監督, コントロールされるためのシス テムと定義し, 取締役会の構造と手続きに力点が おかれているところが, 米国においては株主の権 益に焦点がおかれているのと好対照である。この 報告では英国上場企業の財務的側面を主として調 查していて，大部分がロンドン証券取引所の上場 基準の要件となっている。社外取締役の役割, 取 締役会に十分な数の社外取締役を入れることの重 要性, 株主に対して企業業績を再評価して報告す
るという取締役の責務, 監査委員会を創設するこ との必要性などが報告書の焦点となっている。こ れらは90年代初期における上場企業数社の（株主 にとっての）予想外の倒産という事件を契機に開 かれた委員会の性格を反映している。そしてこの 報告を進展させたのがハンペル報告である。

またある取締役に対して多額の報酬が支払われ てきたことを受けてグリーンベリー委員会が設置 された。ここでは取締役の報酬に焦点がおかれ， 企業の業績と常勤取締役の報酬の大きな部分が連 動すべきという見解を示し，上場企業の取締役を コントロールするための仕組みとして企業統治を 位置づけている。英国の企業統治は上場企業に対 する株主の信頼性を担保するものと判断していい。 米国と英国を“合併”したかたちで，トロント 証券取引所（カナダ）に扔いては, 企業統治とは 株主価值を増加する目的での，企業の事業と業務 を監督管理するプロセスと構造と位置づけている。 それは株主, 取締役, マネジメントの間の説明責 任を実現するメカニズムを規定するものである。 そして事業の監督管理においては他の利害関係者 である従業員, 顧客, サプライヤーそして地域社 会への影響も考慮しなければならないと規定して いる。

以上のように英国では上場企業に対する株主の 信頼性を担保するシステムとしての企業統治の色 彩が濃いものであるといえる。一方, 米国の場合, 投資収益の向上をめざす機関投資家の役割が企業 統治において指導的であると指摘される。

\section{4. 日本企業における企業統治の課題}

2 節で展開したように, メガコンペティション という言葉に表現されるグローバルベースの競争 の激化に対応し，日本企業に抢いて経営資源の充 実（量の蓄積）に重点をおいた企業戦略を再編成 しなければならない状況になっている。“ほどほ ごの経営資源”の投入ではその事業からの収益は 
期待できないのがこれからである。しかも，企業 戦略の再編成を “ゆっくり”策定している時間の 余裕はあまりないと考えられる。そのため，外部 からみた適切な収益性を求める事業再構築の意思 決定, それを可能にする意思决定システムへの変 換が現在の日本企業に求められている。

と同時に，企業におけるバランス・シートの右 側の変化むまた，新たな企業の対応を要求するす のである。資金調達の重点が社債・株式に移行す るにつれ，市場の収益性の要求に答える，そして 市場が企業の収益性を評価できるような情報の開 示（透明性）が要求される。これまで銀行借入に 大きく依存した時とは異なる情報対応が必要になっ ている。

また，企業は社会の一員であるから, 企業行動 そのものも社会の価值観からは無縁ではない。倫 理, 環境, 雇用といった社会にとって重要な課題 についての企業対応の適切性は常に問われる。

日本企業においては少なくても上に挙げた 3 点 の課題を今, 解決しなくてはならないのは 3 節で 述べた米国，英国企業とは少し状況が異なるであ ろう。米国経済, 米国企業の好業績を受けて, 企 業統治の究極的な形が現在の米国企業の採用して いる形であるとの主張が日本国内で強い。しかし そう判断するのは早計である。米国においても長 い歴史のなかで今のような形を作ってきており， その形は将来変化していく可能性を秘めている。 だといって，これまでの日本企業が維持してきた 企業統治の形をそのまま継続していけると考えて いる人はいまや少数であろう。

要は, 日本企業にとって“ワーカブルな”企業 統治, 将来の企業環境を踏まえての企業統治の仕 組を模索することである。将来に向けて, 活力を 持って収益を獲得できる企業へと移行するための 企業統治の仕組を構築することしかないであろう。

そして, 認識として重要なのは, 企業統治の仕 組だけで十分ではなく，経営者（CEO）の資質, 価値観す重要な要素であるということである。日
本においては企業統治の仕組は経営者に対して市 場，社会からのフィードバックをどう機能させる か, その仕組を構築していくことである。その意 味では当然「企業」というあのをどう定義すべき かという個人の判断，意識が，これからの日本企 業の企業統治のありかたを考察する鍵となろう。 経験的には“企業は誰のむのか?”という議論よ りは“企業は何のために存在するのか?”という 議論のほうが日本ではなじみのあるあのである。 が，このことは市場という海の上に浮かんでいる 船としての企業という認識を企業人に対して希薄 にさせるものであった。ことに投資家から成立す る市場に依存している船という経営陣の感受性が 極めて希薄だったといってよい。

戦後, 日本においては，企業自体がある種の “社会”というイメージを確立してきたのも事実 である。同時に, 企業は営利組織という認識も存 在する。これまでは収益と雇用の両方を同時に追 求できた時期，しかもそのことが効果を生んだ時 期むあったが，これからしばらくは，その可能性 は極めて低く, トレードオフの問題が現在の日本 企業の苦悩かもしれない。

\section{（1）環境変化が要請する制度改革}

つぎに現在 議論が集中している取締役会, 取 締役，監査役会，諮問委員会といった“形”に焦 点を当てよう。まず，どのような形がなぜ提案さ れ，それが有効であるかどうか検討することにす る。まず，取締役会，取締役のありかたに関して はつぎにあげるのが現在の議論の公約数であると いってよい;

「取締役会」

基本は取締役会の形骸化，すなわち無討議，無 発言, 形式化した議事録, 責任感の欠如を避けた, 本来の取締役会の機能を取り戻すことである。そ のためには

1. 法定事項以外の決議事項の明確化

2. 執行役員の監視機能の強化 
3. 取締役会の構成（人数, 選任, 報酬等)

4. 実質的な代表取締役の解・選任権の有無

5 . 報酬・選任・監查委員会の有無と直接接触

6. 議事録作成の内容の充実 等

を検討しなくてはならない。

「取締役」

執行役員としての機能と取締役会メンバーとし ての責任の明確化が鍵である。そして

1. 権限・責任の明確化

2. 選任の方法之適格性

3。報酬

4. 株主からの受託者としての責任の認識 といった点に留意が必要である。

要は企業戦略の策定は執行役員が行い, 取締役 会は策定された企業戦略の承認・評価を行うとい う認識である。執行役員, 取締役という表現に比 重を押くのではなく，企業戦略の策定と，株主 （外部）からみた企業戦略の評価・コントロール という，機能の分離を行うことが現在の日本企業 の企業統治に貢献するとの判断である。これまで の日本企業における取締役, 取締役会の現実は, 経営の意思決定の監督機能と業務執行機能が未分 化であり，また多くの取締役は米国企業における オフィサー（日本における執行役員）の役割を果 たしてきたといえる。したがって業務執行の任に ある取締役が他の業務執行担当の取締役を監督管 理するという機能は（商法には定められているが） ほとんど働かなかったといえる（結果責任は負わ ねばならないが）。さに言えば，日本社会にお いて取締役という地位が企業社会における階層に おいて社員の最終昇進目標になっているという企 業文化の存在む指摘できよう。

しかむ, 日本企業の経営システムの変更は, 単 に取締役と執行役員の分離, 少数の取締役からな る取締役会といった「形だけを優先した」变更で はなく，日本において企業というあのの価值をど う定義すべきかをグローバルな競争のなかで模索 するという困難な課題でもある。企業は利益を追
求する組織と位置づける見方が一方にあれば，戦 後からの経験に基づく“社会 (家庭) 化”した組 織という見方屯存在する。このような多様な見方, “企業は誰のあのか?”之“企業は何のために存 在するのか?”の間で摇れているといってよい。

しかし, “取締役会のありかた”についての議 論がなぜ今になってこれほど強調されるようになっ たかといえば，取締役会の形晐化という指摘があ る。このような指摘は過去においてあなされてき たという認識が重要である。皮肉な表現を使用す れば“活発な取締役会”というあのが戦後の日本 企業に日常的に存在したのであろうかということ である。換言すれば取締役会が最近形骸化したか ら取締役会の問題が露呈したということではない ということである。しかし，そのような取締役会 であってあ日本企業は80年代までは世界で賞賛さ れる業績をあげてきた。2節で検討したように， 企業環境の推移がこれまでの取締役会の欠点, 企 業統治の弱点を浮上させたといえる。

日本企業はこれまで経営資源の蓄積を重視して きた。人材・技術・新規市場開拓・新規事業開拓 上経営資源の蓄積が企業を強化するという認識を 戦略の柱に据えてきた。その反面, 蓄積した経営 資源を時点毎に効率的に活用してきたという証明 には敏感，積極的ではなかったといってよい。し かし，このような企業のスタンスが長期において 維持 (支持) されてきたのも事実である。成長率 の高い国内市場の存在, 有利な為替条件, 銀行を 主体にした間接金融制度の存在，株式持合制度等 が、これまでのスタンスを維持させてきたといえ る。またメインバンク制度を中心とする銀行シス テムが企業統治の一部を担当したとすいえる。

しかし，上に列記したような日本企業の外部環 境は90年代になって大きく変化した。製品市場の 成熟化とメガコンペティションの到来は事業にお いて勝者と敗者の 2 極化現象を生み出しつつある。 単に参加するだけではいつまで待ってもリターン は期待できなくなる“ゲームのルール”が波及し 
はじめた。経営資源の蓄積がいつかは長期的収益 を保障するかもしれないが，それまで企業は存在 できるか可能性は低まり，“選択と集中”という 表現にみられるように投資経営資源の “閾値” と いう概念が注目されるようになった。このような “ゲームのルール”の变更前において過度の多角 化・投資をバブル期までに行った企業が現在， スマッチによる経営資源の再配置に苦悩している のである。また，市場の需要・競争条件の変化が 加速しつつあるので，企業における意思決定の夕 イミング自体も収益性に影響を与えるようになっ た。一歩いつも遅れることは過去と異なり，企業 の収益性にとってリスクの高い行動となりつつある。

そのようなリスクの高まる環境のもと，企業へ の投資家は企業の市場戦略の収益性をこれまで以 上に強く問うようになってきた。企業は投資家の 関心にこれまでのように鈍感ではいられなくなり つつある。今後年金基金その他の存在が進めば, 投資家としての株主はますます企業に対して高い 収益性を問うようになろう。また，社債市場にお いては企業の格付が重要なシグナルになっている ことは衆知のことである。格付という“他人の評 価”が企業の資金調達コストに大きな影響を与え る世界になっている。

換言すれば，資金調達に占める社債・株式の割 合が高まるなかで，企業を外からみた評価（市場 の評価）が鍵となりつつあるということを示す。 その意味でバランス・シートの右サイドの変化が 企業経営システムの变更をいや拉うなしに要求し ているのである。バランス・シートの左サイドの 収益性を問うようになったのである。また，外人 株主（純粋な投資家）の比率が高い企業が経営シ ステムの変更の先を歩みつつあるという事実は上 の議論を補足するものである。

要するに, 企業の市場戦略の展開において夕イ ミングそのものの要求が高まり，また競争戦略の 強化のためには経営資源の重点投資が要請される ようになった。また企業への投資家は収益性の担
保を要求し，その収益性を外部から計算できるよ うな経営の透明性を要求しはじめたのである。こ のような要請に対応できない場合, 企業の存在感 が後退していく確率が高まりつつあるのが現況と いえる。

\section{（2）制度改革の有効性}

ここで現在進行中の企業統治における制度改革 の有効性を検討してみよう。実施されている取締 役会の制度改革は，取締役の数を削減して，何人 かの取締役を執行役員にするという形が多い。時 間をどの程度かけるかにより，取締役から執行役 員へのシフトの形をとるか，これまで取締役にな れた人をまずは執行役員にするという形をとるか に分かれる。そして少数の取締役からなる取締役 会で企業戦略の検討をし，半数に満たない社外取 締役をそれに参加させるという形をとると思われる。

しかし，これは“形”の議論にすぎない。形の 変更が有効性を発揮するという保障はない。例え ば，米国において優良企業において社外取締役の 比率が高いということがあっても，社外取締役が 企業の収益性の向上に機能しているのか，または， 収益性を高く維持できてきた企業だからこそ，外 部環境に敏感なので, その結果, 社外取締役の比 率を高めているのかはさだかではない（相関の世 界)。また 取締役と執行役員の分離が企業業績に 高い効果があるかどうかも今後の調查を待たねば ならない。株主の利害の代理人としての取締役と いう視点は重要であるが，同時に，これからは企 業にとって長期的な視野からの“望ましい株主” という視点も浮上してくるであろう。

ここで日本企業における取締役, 監査役として 執行役員の機能についてこれまでどのように働い てきたかを考察する。一番の課題は, 執行役員と しての機能と, 取締役会のメンバーとしての責任 の明確化にある。これまでの日本企業の取締役は 執行役員としての機能を果たすことで十分と認識 してきたと述べた。問題はそのような執行役員の 
行為を株主の視点で監視すべき機能があまり働い てこなかったことにある。あちろん会計監査はな されてきたであろうが，業務監查が，ことに株主 の視点にたってなされてこなかった傾向がある。 換言すれば本来の取締役会の機能が働いてこなかっ たといえる。したがって執行役員はあまり株主と の間の緊張感を“自然に”感じてこなかった。顧 客・従業員・組合といった集合との緊張感を優先 した結果, 資本効率の低下に敏感に対応しなかっ た。そこで現在, 株主からの正当な“摇り戻し” を受けているといってよい。

あちろん，執行役員はこれまで取締役を兼ねて いたから，他の取締役（執行役員）の監視をすべ きであったとは理屈では主張できるが，取締役の

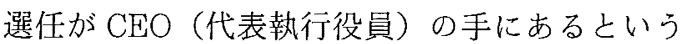
現状では取締役にはそのような監視のインセンティ ブは働かないと判断できる。執行役員における階 層性が取締役会にも働いているのが現状である。

取締役が執行役員の監視の機能を果たさないの なら監查役が取締役でもある執行役員の監視をす べきであったといえる。しかし，現状において CEO が実質的に選択する監查役で，しかも調查 要員をあまり持たない現状ではそれあ期待できな いであろう。

要するに執行役員の行動を監視（評価）する仕 組が商法上あるとはいえ，現実には機能していな いし，また現実の取締役もそのような機能を期待 されているという意識は極めて薄いし，またイン センティブあ存在しない。そのような状況下にお いて，日本企業の取締役執行役員はあたりまえに 執行役員としての機能だけを果たしてきたといえ る。

\section{（3）制度改革の方向性}

ではどうすべきか？これまでの日本企業の経 営システムの仕組を踏襲すれば CEO という個人 の力量に期待するという方法がある。そして株主 としては $\mathrm{CEO}$ の人選，選択に最大限の関心を払
うことが最適ということになる。取締役の人選， 執行役員の監視などの仕事を優秀な CEO に委託 するということである。しかし，CEOの選択の 十分な情報を株主が持つことが可能であろうか， そしてそのようなことに係わるインセンティブを 株主が持つかということになろう。それよりは市 場で株を売却するという，その企業からの退出が 自然であろう。もちろん，大株主や金融機関がそ のような役割を果たしてきたという過去の例むあ る。それに代わるものとして将来は，外部からの 参加者が多数を占める諮問機関が，その決定に拘 束力を持てれば， $\mathrm{CEO}$ の選択に関与するという 案あある。これらは $\mathrm{CEO}$ 個人に対して外部から の“圧力”を効加ることにより，経営における 緊張感を持たそうということである。そのような 諮問機関の構成員に CEO にそのような圧力をか けるインセンティブが設計できるかという問題は 残る。

$\mathrm{CEO}$ の株主による人選が実際的ではないとし たら，他の方法としては取締役会のトランスフォー メイションであろう。無討議, 無発言, 形式化し た議事録といった形骸化を避け，執行役員の策定 した企業戦略の承認と評価を主体にして，企業の 方向性，倫理，環境問題などを議論，決定する機 関に取締役会を変えることである。その場合，取 締役の人選は $\mathrm{CEO}$ を除くと，外部からという確 率が高くなるであろう。そしてこれまで取締役会, 経営会議などで行われてきた行為はすべて執行役 員からなる組織で決定されることになる。この形 は現在の米国企業で採用されている方式である。

上に述べたことは，現在日本企業で採用されて いる，監查役制度や諮問機関，アドバイザリーボー ドの役割の多くを取締役会に移行させるというこ とである。したがって，これまでの日本企業にお ける “役員”という称号はすべて執行役員を指す ということになろう。社外取締役という制度に対 して，“外の人に事業が分かるのか?”という反 論があるが，事業における意思決定は執行役員が 
行うのであるから，そのような反論は適切とはい えない。もちろん, 社外取締役の選択の問題は重 要である。米国, 英国の例にみられるように，社 外とは独立取締役を意味することになろう。広い 経験, 高い学識と教養から選任され, 取締役会に 価値ある洞察をむたらす専門的知識の提供ととむ に，マネジメントの監視という点で，マネジメン ト・利害関係者から独立していることが重要であ る。これは個々の取締役の能力というよりはシス テムとしての有効性の問題である。しかし, 独立 取締役にとってのインセンティブは何であるかと いう問題は依然残る。

要するに，どのような経営システムの形をとっ ても問題は残るということであり，状況に応じて 経営システムを変化させていかなければならない ということであろう。したがって，これから将来 にかけて日本企業にとってどのような課題を最優 先すべきかによって経営システムは決まるであろ う。

\section{（4）企業設計：トップの付加価値}

企業設計の担当である現在の日本企業のトップ マネジメントにとって考慮しなければならない点 は乱暴にいって2つに集約されると思われる。ひ とつは『企業統治』はどうあるべきかということ であり，あうひとつは『企業戦略の再構築』であ る。これまでのミドル・アップという日本企業の 長所は維持すべきかと判断できるが，これら $2 つ$ はまさにトップの責務である。その意味ではこれ からの企業設計で問われているのは『トップの付 加価值』ということであろう。

企業戦略の再構築においての重要課題は“将来 の当社の収益はどの分野から獲得すべきか?”之 いう戦略課題の解決と, そのことを社員が実行し やすくするために“どのような経営組織・評価シ ステム”を構築すべきかということである。コア 事業，選択と集中ということは前者への指針であ り，そのことは継続している事業そのあのの“機
会費用”を強く意識した経営資源配分をこれから はしなければならないということを意味する。お ちろん日本の企業においては将来に向けての経営 資源再配分の方向性検討はすでになされているで あろうが，実はむっと頭を悩ます問題は，そのよ うな変革に対してどの程度の時間が市場によって 許されているかの判断である。10年経てば環境变 化に順応して企業は自然に変化するであろうが, 何年以内で変革しなくてはならないのかという判 断，これは日本企業のトップ層においても多様な 幅を持っている。企業戦略の変革の方向性のみな らずその速度を意思決定すること，このことこそ トップが企業に附加すべきあのであると思われる。 このことはトップが株主の代理人という認識をもっ ていれば幾分容易なのかもしれないが，“従業員 の代理人”という意識を強く持ちすぎていると 『連続性』を重視するあまり，この判断に楽観的 なバイアスがはいる可能性が高い。現在の状況で は，企業は営利を持続的に獲得する組織との要請 の下，“株主の代理人”という視点を強調するシ ステム設計が優先されるべきではないかと思われる。

また，スピード経営を達成するためには，“に゙ こで意思決定のスピードが落ちているかの分析” をしなければならない。取締役と執行役員の分離, 分社制などという制度・組織の变革も重要ではあ るが，それ以上に重要なのはトップマネジメント による『明瞭な戦略と明確な意思決定』ではなか ろうか。『暗黙の戦略と部下への多様性を持つ指 示』が続くようでは組織を簡素化しても“自然渋 帯の高速道路”と表現されてむよいスピードの経 営となろう。要は, これまでのトップマネジメン トの責務が『本来の責務』にもどるべきというこ とである。当然，それに対応して報酬制度も変更 されるべきであろう。

日本企業における企業統治の問題の元凶は，戦

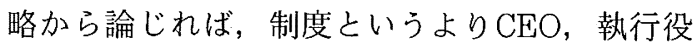
員というマネジメントの付加価值そのものが問わ れているといえる。 
(5) CEO の選択・ネガティブ・フィードバック 機能

現在の日本企業においては CEO の権力は強大 である，それを行使しているから゙うかは別にして あ。したがって企業変革に打いて CEO が変革の リーダーになれば企業変革は容易という考えあで きよう。問題は CEO が誰をみて，何をみて行動 するかであろう。誰が $\mathrm{CEO}$ か, そしてその人の 価値観，世界観のありかたがその企業の将来像に 与えるインパクトは過去に比較して格段に高まる であろう。“経営は人 (トップ)”ということは 否定できないが, 同時に, システムとして経営の 品質を維持することあ重要である。そのためには CEO に対するネガティブ・フィードバック機構 の設定が必要である（ある法律学者の言によれば, 馬車の御者が取締役会, 先頭の馬が $\mathrm{CEO}$ という ことになろう。しかし，多くの CEO は御者のつ ありである)。形の上では取締役, 監查役が存在 するが，現実にはそれら取締役・監査役は日本企 業においては CEOが選択しているので, CEO により選ばれた人々が CEO の評価・選択をする ことを期待するのは現状では無理であるといわれ ている。

そのために, 社外 (独立) 取締役の登用, 諮問 委員会, 独立性をもった監査役制度が試みられて いる。どの方法が個々の企業に合っているかは企 業によって異なるが, CEO からの独立性をいか に担保すべきかが重要と判断できる。また，解決 しなけ机ならないのは, それらの人々が積極的 関与するようにどのようなインセンティブを設計 すべきかということである。どの方法がいいのか は多様な見方が存在しているが, 現状では “原理 的な”議論ではなく，何がうまく“ワーク”する かという視点でシステムの改良を積み重ねていく という姿勢を持つべきではなかろうか。ただし， 一部にみられるような取締役と執行役員の役割の 混同による䛊解は避けるべきであろう。これまで の日本においては多くの取締役は実は執行役員と
しての役割だけを果たしてきているといってよい であろう。その結果, 内部志向の色彩が強く反映 された。そこで, 企業戦略の策定・執行の任に当 たる役割と，株主および社会の立場から，その戦 略を承認・評価する役割を『制度（システム）』 として分離することはどのようなフィードバック 機構を設計してあ必須ではなかろうか。形式的と 言われるが，企業の意思決定プロセスを大きく Decision Control と Decision Managementに 分離する，換言すれば 投資計画の策定，計画案 の選択，投資の実行，そして成果の監督となる一 連の意思決定において，投資計画の策定と選択さ れた投資の実行がマネジメントの領域に，そして 計画案の選択と実行された投資の成果の監視が取 締役会の領域という分離が必要かと判断される。 これまでの日本企業は上記のすべてをマネジメン トが担当し，その結果として市場・社会からのネ ガティブ・フィードバックが機能しなくなったの ではと考察できる。

\section{5. 最後に}

製品市場の成熟化，グローバル競争の激化，資 金調達における間接金融から直接金融へのシフト， 他人の評価が資金調達コストに響く格付機関，株 主としての年金基金や機関投資家の存在，グロー バル化による外人株主の増加, 株式持合の解消, 国際的な会計ルールの要求と, 多くの企業環境の 推移がこれまでの日本企業の経営インフラを崩壊 させつつある。そこで市場・社会からのフィード バックが機能する新たな仕組が需要され，そこに おいては投資家が投資の収益性の担保を企業に要 求し, しかもその収益性の計算を外部からできる ような経営の透明性を求めている。また株主の代 理人としてマネジメント（執行役員）の行動を監 督する機能組織の確立をあ要求している。これら が日本における企業統治の問題の核であると思わ れる。 
この企業变革の過程においては，CEOの個人 としての市場観, 価值観, 企業観が重要であるこ とはいうまでもない。そこで，どのような視点を 持つべきかを，CEO 抢よびに CEO 候補者が 『学びっづける』という姿勢が望まれる。そのた めにも, システムとして CEO に企業の外側の視 点からネガティブ・フィードバックしていくこと が必要である。そのためにも取締役会と業務執行 役員の分離が重要な手段のひとつである。

極論すれば株主持分の最大化という目的関数に 対して，企業としてどのような制約条件を設定し ていくのか，そのことが企業の価値観であり，企 業経営の課題となる。グローバル・スタンダード に対する反発ああるが，米国を含め，他企業の参 考にできるガバナンスのありかたを“ベスト・プ ラクティス”として自社のなかに組み入れていく という多様性を認めた実験, それが現在の日本企 業における企業統治のシステム設計に求められて いるのではなかろうか。

株式会社の特徵, それは所有と経営の分離であ り，そのことによってリスクの高い経済活動に企 業が従事できるようになった。その結果は社会に とってあ望ましいあのでああった。しかし, 企業 成長に伴う企業活動の拡大・複雑化は一方で経営 の専門化を要求し, マネジメントの権限を強化。 拡大していった。また同時に外部株主の経営に関 する関心は希薄化していった。このような状態で, 経営情報の偏在がマネジメントの自己利益・効用 を優先する可能性を産出した。まさに“残余財産 権者として弱い立場にいる”株主によって“エー ジェンシー問題”が無視できない状況が出現した のであった。

また，企業の成長は，利害関係者の増大を産み， “企業の社会化”という表現があてはまるように なり，社会制度のなかで企業が果たす役割む加速 度的に増加した。企業行動自体が社会において

“質点の動き”として位置づけできなくなった。 企業の意思決定が社会に与える影響が無視できな
いほど増大したといえる。

このような状況に扔いてわれわれが模索するの は最適解としての企業統治の原形ではなく, 日本 企業にとっての“ワーカブルな企業統治”であろ う。それは当面, 経営による内部監查の充実, 説 明責任の強化, 経営の透明性の強化を伴って執行 役員と取締役の分離ということになるのではなか ろうか。ワーカブルという表現は, 企業統治の様々 な提案（監查役会の充実とはトータルに学ぶとい うことで，最初に都合のよい部分だけをむってく るべきではない。

企業統治ということは CEOに対して制約を課 すものだという認識も多い。しかし，この制度は 変化の時期において CEO がスピード経営を実行 するための “安全な場”を設定するものである。 ある種の制度を設定しているからこそ経営のスピー ドを上げてあスピード違反で捕まらないのだとい う認識が必要である。そこで要請される形は『リー ダーシップを持った $\mathrm{CEO}$ と彼に外部の視点で強 くフィードバックをかける取締役会』, この“緊 張感”を持った CEO と取締役会のインタラクショ ンの設計こそ日本企業における企業統治の設計原 理ではなかろうか。

\section{参考文献}

「日本企業の取締役ならびに取締役会の課題」研究報 告, 日本能率協会, 1999年

フリードマン, トーマス（2000『レクサスとオリーブ の木：グローバリゼーションの正体, 上・下』草思 社

矢作恒雄, 青井倫一, 嶋口充輝, 和田充夫 (1996)『イ ンタラクティブマネジメント：関係性重視の経営』 ダイヤモンド社

Institute of Directors (1999) Standards for the Board. London : Institute of Directors.

Jensen, Michael C. (1998) Foundations of Organizational Strategy. Harvard University Press. 


\title{
Japanese Firms and the Design of the Corporate Governance System
}

\author{
Michikazu Aoi, D. B. A.*
}

\begin{abstract}
This paper focuses on the system design agenda of the corporate governance structure for Japanese firms. Japanese firms that had once enjoyed the Japanese dreams of the late 80 's now face many difficulties in strategies, organizations and particularly management systems. These have resulted from the shift of the environment which surrouns them. The rules of the game have changed drastically and Japanese firms have to rearrange or redesign what they once thought to be right.

Many lessons can be learned from the corporate governance systems of the U.S.A. and the U.K., but most of the difficulty lies on the type of capitalism for which they stand. The relational-based capitalism on which they are based may not be effective during a rapid change of environment. Should Japanese firms redesign themselves for market-based capitalism? Some measures are discussed in this paper from the viewpoint of the "demand analysis" of corporate governance.
\end{abstract}

Keywords : Corporate governance, Strategy of Japanese firms, Value added of top management, Directors' boards

* Graduateschool of Business Administration, Keio University 